\title{
Erratum
}

\section{Review of Trade-Related Investment Measures: Theory and Applications}

\author{
SERGEY F. SUTYRIN, ELENA G. EFINOVA AND OLGA Y. TROFIMENKO \\ doi:10.1017/S1474745616000094, published by Cambridge University Press, \\ June 2016, pp 540-542.
}

The above book review was published with one of the authors' names spelled incorrectly. The second listed author's name was shown as Elena G. Efinova and should have been shown as Elena G. Efimova.

We apologise for the error.

\section{Reference}

Sergey F. Sutyrin, Elena G. Efinova and Olga Y. Trofimenko (2016). Review of 'Trade-Related Investment Measures: Theory and Applications' World Trade Review, 15, pp 540-542. 